\title{
Pengembangan Model Pembelajaran Berbasis Aktivitas Jasmani Untuk Karakter Demokratis Tema 2 Subtema 1 Bagi Siswa Kelas IV SDN Bendan Ngisor Semarang
}

\section{Faris Himawan}

Program Studi Pendidikan Guru Sekolah Dasar; FIP Universitas PGRI Semarang; Jl.

Sidodadi Timur No 24, Dr. Cipto Semarang 50125 Jawa Tengah; farishimawan22@gmail.com

\begin{abstract}
Abstrak. Penelitian ini diawali dari sebagian besar siswa yang masih banyak dalam karakter anak masih kurang mulai dari berbica sendiri tidak mematuhi peraturan dan tidak mendengarkan gurunya dalam pembelajaran penjas. Permasalahan tersebut menjadi pertimbangan bagi peneliti untuk melakukan penelitian. Penelitian ini bertujuan untuk mengahasilkan model pembelajaran aktivitas jasmani dengan menggunakan permainan tradisional. Penelitian ini dilakukan kepada siswa kelas IV di SD Bendan Ngisor Semarang. Jenis penelitian ini adalah penelitian dan pengembangan yang diadaptasi dari Borg and Gall yang kemudian pada tahap pengembangan dibagi menjadi beberapa langkah-langkah yaitu (a) penyusunan draft model awal pembelajaran, (b) validasi ahli, (c) uji coba skala kecil, (4) uji coba skala besar, dan (e) produk operasioanl terbatas. Hasil dari penelitian berdasarkan perhitungan normatif berkategori baik, berkategori baik artinya model yang dikembangkan dapat mengembangkan karakter siswa, dan model yang dikembangkan sesuai dengan karakteristik dan pembelajaran penjas.
\end{abstract}

Kata Kunci: Pendidikan karakter, Demokratis.

\begin{abstract}
This study was started from the majority of students who are still many in the character of children are still lacking from the self-talk is not approved by the rules and not read by the teacher in learning pysical of education. These problems become a consideration for researchers to conduct research. This study aims to produce a model of learning physical activity using traditional games. This research was conducted to fourth grade students at SD Bendan Ngisor Semarang. This type of research is research and development adapted from Borg and Gall which is then divided into several steps in the development stage, namely (a) preparation of the initial learning draft model, (b) expert validation, (c) small-scale trials, (4) large-scale trials, and (e) limited operating products. The results of the study are based on the normative calculation of good category, good category means that the developed model can develop the character of students, and the model developed in accordance with the characteristics and learning of Physical Education
\end{abstract}

Keywords: character building, democratic.

\section{Pendahuluan}

Setiap anak memiliki hak yang sama untuk mendapatkan pendidikan. Melalui pendidikan anak dapat mengembangkan potensi yang ada pada dirinya.Pendidikan yang baik dan berkualitas bagi sebuah negara merupakan aspek penting untuk menentukan masa depan kehidupan negara itu sendiri.Pendidikan yang berkualitas menjadi penting sebab dengan pendidikan, manusia mampu mengembangkan nalar berpikirnya. 
Pendidikan dapat dilakukan di sekolah maupun di luar sekolah. Elfachmi (2016: 12) mengatakan bahwa pendidikan merupakan usaha mendapatkan pengetahuan baik secara formal melalui sekolah maupun secara informal dari pendidikan didalam rumah dan masyarakat. Pendidikan disekolah dilaksanakan secara langsung dengan kegiatan pembelajaran dan terjadinya interaksi antar guru dengan peserta didik agar suatu tujuan pembelajaran dapat di capai dengan baik, pendidikan di sekolah meliputi kegiatan belajar mengajar, berdiskusi dan menemukan hal-hal baru. Pendidikan diluar sekolah dapat terjadi antar peserta didik dengan masyarakat dan lingkungan sekitar. Pendidikan dicapai agar peserta didik memilki kesadaran untuk mengembangkan kemampuan dan kepribadiannya sesuai dengan pendapat Fudyartanta (2010: 9) pendidikan merupakan usaha sadar untuk mengembangkan kemampuan dan kepribadian anak, berlangsung baik dalam keluarga, sekolah maupun di masyarakat dan berlaku seumurhidup.

Sebagai pedoman dalam menyelenggarakan pendidikan nasional didalam Undang-Undang Nomor 20 Tahun 2003 pasal 3 tentang Sistem Pendidikan Nasional, menyatakan Pendidikan Nasional adalah mengembangkan kemampuan dan watak serta peradaban bangsa yang bermartabat dalam rangka mencerdaskan kehidupan bangsa dan tujuan pendidikan nasional untuk mengembangkan potensi peserta didik agar menjadi manusia yang beriman dan bertakwa kepada Tuhan Yang MahaEsa, berakhlak mulia, sehat, berilmu, cakap, kreatif, mandiri, dan menjadi warga negara yang demokrtais serta bertanggung jawab.Dari Undang-Undang ini, bahwa garis besar dari tujuan pendidikan nasional adalah selain mencerdaskan peserta didik ,juga terciptanya karakter peserta didik yang beriman, mandiri dan berakhlak mulia.Pendidikan karakter di Indonesia telah lama menjadi perhatian pemerintah dalam Undang-UndangNomor 20 Tahun 2003 tentang sistem Pendidikan Nasional pada pasal 1 menyatakan Pendidikan adalah usaha sadar dan terencana untuk mewujudkan suasana belajar dan proses pembelajaran agar peserta didik secara aktif mengembangkan potensi dirinya untuk memiliki kekuatan spiritual keagamaan, pengendaliandiri, kepribadian kecerdasan, akhlakmulia, serta ketrampilan yang diperlukan dirinya, masyarakat bangsa dan negara.

Selamaini, pendidikan informal terutama dalam lingkungan keluarga belum memberikan kontribusi berarti dalam mendukung pencapaian kompetensi dan pembentukan karakter pesertadidik.Kesibukan dan aktivitas kerja orang tua yang relatif tinggi, kurangnya pemahaman orang tua dalam mendidik anak di lingkungan keluarga, pengaruh pergaulan dilingkungan sekitar dan pengaruh IPTEK yang akhir ini berkembang sangatcepat yang 
tidak diawasioleh orang tua berpengaruh negatif terhadap perkembangan anak. Salah satu alternatif untuk mengatasi permasalahan tersebut adalah melalui pendidikan karakter di sekolah.Menurut Noor (2012: 35-36) pendidikan karakter adalah proses pemberian tuntunan anakdidik agar menjadi manusia berkarakter dalam dimensi hati, pikir, raga, serta rasa dan karsa. Faktor keluarga sangat berperan dalam membentuk karakter anak. Namun, kematangan emosi sangat dipengaruhi oleh lingkungan sekolah sejak usia dini sampai usia remaja. Menurut Mahbubi (2012: 41) pendidikan karakter adalah system penanaman nilai-nilai karakter pada warga sekolah meliputi komponen pengetahuan, kesadaran dan tindakan untuk merealisasikan nilai tersebut.

Sekolah adalah tempat yang strategis untuk pendidikan karakter karena anak-anak akan mengenyam pendidikan di sekolah. Selain itu anak menghabiskan besar waktunya di sekolah, sehingga apa yang didapatkan di sekolah akan mempengaruhi pembetukan karakternya. Pendidikan karakter demokratis merupakan salah satu karakter yang harus diterapkan di sekolah menurut Badan Penelitian dan Pengembangan Pusat Kurikulum Kementrian Pendidikan Nasional. Sikap demokratis merupakan kepribadian seseorang yang mendorong siswa untuk bertindak sesuai nilai-nilai yang terkandung dalam demokrasi. Dengan adanya sikap demokratis, maka seorang siswa juga akan mempunyai sikap nasionalisme, bertanggung jawab, tidak memiliki prasangka buruk, saling menghargai bila terjadi perbedaan pendapat, tidak langsung mengambil sikap arogan, dapat mengkomunikasikan terlebih dahulu bila terjadi masalah sehingga tidak terjadi kecenderungan untuk berperilaku agresif seperti perkelahian yang berujung tawuran dan memfitnah. Dengan demokrasi siswa diberikan kesempatan yang luas untuk mengembangkan potensi yang dimiliki. Demokrasi harus mengakui bahwa setiap siswa mempunyai hak dan kewajiban yang sama. Hal ini berarti bahwa di dalam proses pembelajaran guru dan siswa memliki posisi yang sama yaitu sedang mencari pengetahuan dan pengalaman baru.

Pendidikan karakter dalam sistem pendidikan nasional telah terintegrasi di berbagai mata pelajaran salah satunya Pendidikan Jasmani, Olaharaga dan Kesehatan penjas. Pembelajaran Penjasorkes sangat menarik untuk dihubungkan dengan pendidikan karakter karena siswa harus hadir tepat waktu di jam pertama, mematuhi peraturan dalam pembelajaran penjasorkes, serta pembentukan regu permainan siswa harus diskusi dengan saling menghargai. Hal ini merupakan suatu bukti dimana mata pelajaran penjasorkes berperan aktif dalam membentuk karakter bangsa. Salah satu 
tujuan mata pelajaran pendidikan jasmani, olahraga dan kesehatan menurut Rosdiani (2013: 144) adalah mengembangkan sikap sportif, jujur, disiplin, bertanggung jawab, kerjasama, percaya diri dan demokratis.

Berdasarkan latar belakang di atas, penelitian ini ingin mengetahui lebih dalam tentang pendidikan karakter demokratis khususnya dalam pembelajaran penjas yang dirumuskan dalam judul "Pengembangan Model Pembelajaran Berbasis Aktivitas Jasmani untuk Karakter Demokratis Tema 2 Subtema 1 Bagi Siswa Kelas IV SDN Bendan Ngisor Semarang"

\section{Metode}

Berdasarkan permasalahan yang dikaji yaitu pengembangan model pembelajaran berbasis aktivitas jasmani untuk karakter demokratis tema 2 subtema 1 bagi siswa kelas IV sdn bendan ngisor semarang,maka pendekatan yang digunakan dalam penelitian ini menggunakan pendekatan Research and Development ( $R$ and D). Menurut Borg dan Gall (1979:626) "Educational Research and Development is a process used to develop and validate educational product"Penelitian ini dilaksanakan dengam menggunakan metode pengembangan model yang dikenal dengan research and development. Metode ini dipilih sesuai dengan sasaran dan tujuan akhir penelitian ini yang ditujukan untuk menemukan serta mengembangkan model permainan tradisional menjadi model permainan edukatif yang dapat dipergunakan sebagai pendidikan karakter pada lembaga SD. Tahap pengembangan dibagi menjadi beberapa langkah-langkah yaitu (a) penyusunan draft model awal pembelajaran, (b) validasi ahli, (c) uji coba skala kecil, (4) uji coba skala besar, dan (e) produk operasioanl terbatas.

Adapun penjelasan dari langkah-langkah pada tahap pengembangan sebagai berikut: Penyusunan Draf Model Awal Hasil dari pengembangan berupa draft rancangan awal (prototype) mengenai pengembangan model pembelajaran permainan tradisional untuk siswa sekolah dasar kelas atas. Draft model pembelajaran yang dihasilkan berupa desain model pembelajaran dan implementasi. Draft model pengembangan berupa buku panduan selanjutnya dilakukan validasi model dan uji coba model. Validasi Ahli Validasi model merupakan tahapan untuk mengetahui kelayakan dari draft yang telah disusun. Validasi dilakukan dengan menyerahkan draft model kepada para ahli untuk mendapatkan kesahihan instrumen dan draf. Validasi dari para ahli materi, yaitu: (1) pakar pembelajaran pendidikan jasmani, (2) pakar pendidikan jasmani (guru penjas SD) dan (3) pakar ahli media. Uji Coba Skala Kecil Uji coba kecil dilakukan untuk mengetahui tingkat implementasi model yang dikembangkan. Uji coba skala kecil 
menekankan pada aspek muatan (subtansi isi dan pelaksanaannya) bukan pada hasil (outcomes). Pada uji coba skala kecil dilakukan dengan mengimplementasikan model permainan tradisional yang dilaksanakan satu sekolah yaitu SDN Bendan Ngisor yang berjumlah 32 siswa. Guru menjalankan model pembelajaran dengan menggunakan rancangan model permainan yang dikembangakan. Uji Coba Skala Besar Uji coba secara besar dilakukan 32 siswa SDN Bendan Ngisor pada siswa kelas atas. Setelah dilakukan uji lapangan lebih luas, dilakukan revisi hasil uji kajian produk akhir. Produk Akhir Setelah dilakukan uji coba skala besar, maka dihasilkan model produk akhir. Produk akhir merupakan model permainan tradisional untuk membangun karakter siswa sekolah dasar kelas atas yang sudah dapat implementasikan oleh guru sekolah dasar kelas atas dalam pembelajaran sesungguhnya.

Penelitian ini dilaksanakan di SD Negeri Bendan Ngisor Semarang. Penelitian dilakukan pada 25 November 2019. Subjek Penelitian Subjek dalam penelitian ini adalah siswa kelas IV yang berjumlah 32. Teknik pengumpulan data dalam penelitian ini melalui teknik reduksi data, penyajian data, dan kesimpulan. Instrumen penelitian ini terdiri dari pedoman wawancara, pedoman observasi, dan dokumentasi yang berhubungan dengan pembelajaran. Pengujian keabsahan data menggunakan triangulasi sumber dan teknik, member check, dan cross check.

\section{Hasil dan Pembahasan}

Uji coba lapangan pada model permainan tradisional baik skala kecil maupun besar dilaksanakan setelah mendapat validasi atau standar kelayakan dari ahli pembelajaran penjas. Instrumen validasi draf awal model permainan tradisional oleh ahli pembelajaran penjas maupun guru partisipan menggunakan instrumen angket. Adapun hasil dari penilaian validasi para ahli terhadap draf awal permainan tradisional adalah dapat dilihat Tabel 1.

Tabel 1. Penilaian Validasi oleh pembelajaran penjas dan guru partisipan

\begin{tabular}{|c|c|c|c|c|}
\hline \multirow{2}{*}{ No } & \multirow{2}{*}{ Permainan } & \multicolumn{3}{|c|}{ Skor Penilian } \\
\cline { 3 - 5 } & & A1 & A2 & A3 \\
\hline 1 & Goteng & 77 & 83 & 85 \\
\hline 2 & L.Papan & 73 & 79 & 84 \\
\hline 3 & Kasti Tangan & 80 & 86 & 87 \\
\hline
\end{tabular}


Tabel 1 menunjukkan penilaian ahli materi terhadap draf awal model permainan tradisional berdasarkan karakter sebagai pembelajaran pendidikan jasmani bagi anak sekolah dasar kelas atas. Total nilai para ahli materi untuk permainan goteng, permainan lari papan/ segi empat, dan permainan kasti tangan semua terletak pada interval $66 \leq \mathrm{X}$. Jadi, penilaian para ahli materi terhadap draf awal model permainan tradisional berdasarkan karakter sebagai pembelajaran pendidikan jasmani bagi anak sekolah dasar kelas atas berkategori baik.

Tabel 2. Kategorisasi Penilaian Validasi Ahli Pembelajaran Penjas dan Guru

\begin{tabular}{lccccccccccc}
\multicolumn{11}{c}{ Partisipan } \\
Kategori & \multicolumn{11}{c}{ Nama Permainan } \\
& \multicolumn{1}{c}{ Goteng } & \multicolumn{1}{c}{ Lari Papan } & \multicolumn{3}{c}{ Kasti Tangan } \\
& A1 & A2 & A3 & A1 & A2 & A3 & A1 & A2 & A3 \\
& f & f & f & f & f & f & f & f & f \\
\hline Kurang & - & - & - & - & - & - & - & - & - \\
Cukup & - & - & - & - & - & - & - & - & - \\
Baik & 77 & 83 & 85 & 73 & 79 & 84 & 80 & 86 & 87 \\
\hline
\end{tabular}

Berdasarkan penilaian para ahli materi terhadap angket validasi, terlihat bahwa total nilai draf awal model permainan tradisional telah memenuhi persyaratan kelayakan untuk diujicobakan di lapangan. Penghitungan ini menjadi dasar bahwa draf model permainan tradisional sebagai pembelajaran pendidikan jasmani untuk membangun karakter bagi anak sekolah dasar kelas atas adalah layak untuk dilakukan uji coba skala kecil.

Uji Coba Skala Kecil Uji coba skala kecil dilakukan pada anak kelas atas SD Bendan Ngisor dengan jumlah 32 anak. Pelaksanaan uji coba skala kecil direkam dalam DVD kemudian diobservasi oleh observer (ahli pembelajaran pendidikan jasmani, ahli media dan guru penjasorkes sekolah dasar). Data yang diperoleh dari observer berupa: (1) data hasil observasi penilaian karakter permainan tradisional, (2) data hasil observasi pengembangan tradisional, (4) data hasil observasi keefektifan model permainan tradisional, (5) data hasil penilian observasi ahli media, (6) data hasil evaluasi siswa dan (7) saran perbaikan. Data uji coba dengan skala kecil model permainan tradisional terdiri dari 3 jenis permainan yang bertujuan untuk membangun karakter (kerja sama, kejujuran, percayadiri, dan peduli sesama) pada siswa SD kelas atas. Adapun hasil uji coba skala kecil adalah sebagai berikut:

Tabel 3. Hasil Uji Coba Skala Kecil

\begin{tabular}{ccc}
\hline No. & Penilaian & Kategori \\
\hline 1. & Guru Partisipan & Baik \\
\hline
\end{tabular}




\begin{tabular}{ccc}
\hline No. & Penilaian & Kategori \\
\hline 2. & Ahli Media & Baik \\
3. & Siswa & Baik \\
\hline
\end{tabular}

Berdasarkan kategori penilaian semua item hasil uji coba skala kecil berkategori baik. Hasil penilaian karakter pada uji coba skala kecil terhadap pengembangan model permainan tradisional untuk membangun karakter disajikan sebagai berikut.

Tabel 4. Hasil Uji Coba Karakter Skala Kecil

\begin{tabular}{cccc}
\hline Penilaian & TM & M & SM \\
\hline Guru Partisipan & 3 & 10 & 13 \\
\hline
\end{tabular}

Hasil penilaian karakter pada guru penjas pada uji coba skala kecil terhadap pengembangan model permainan tradisional mendapat total nilai TM: 3, M: 14, SM: 13 poin dengan presentase TM: 10\%, M: 46,7\%, dan SM: 43,3\%. Berdasarkan penilaian guru penjas, terlihat bahwa total penilaian karakter dapat dikatakan baik dengan katagori memenuhi $46 \%$ dan sangat memenuhi 43,3\%. Uji Coba Skala Besar Proses revisi terhadap draf model permainan tradisional yang diujicobakan pada skala kecil ditindaklanjuti dengan melakukan uji coba lapangan skala besar.

Uji coba skala besar dilaksanakan di SDN Bendan Ngisor dengan jumlah siswa 32. Pelaksanaan uji coba skala besar direkam dalam DVD kemudian diobservasi oleh observer (ahli pembelajaran pendidikan jasmani, guru penjasorkes SD, dan ahli media). Data yang diperoleh dari observer berupa: (1) data hasil observasi penilaian karakter permainan tradisional, (2) data hasil observasi pengembangan tradisional (untuk guru dan siswa), (3) data hasil observasi keefektifan model permainan tradisional, (4) data hasil penilian observasi ahli media, (5) data hasil evaluasi siswa dan (6) saran perbaikan. Berdasarkan kategori penilaian semua item hasil uji coba skala besar berkategori baik. Hasil penilaian karakter pada uji coba skala besar terhadap pengembangan model permainan tradisional untuk membangun karakter disajikan Tabel 5.

Tabel 5. Hasil Uji Coba Skala Besar

\begin{tabular}{ccc}
\hline No. & Penilaian & Kategori \\
\hline 1. & Guru Partisipan & Baik \\
2. & Ahli Media & Baik \\
3. & Siswa & Baik \\
\hline
\end{tabular}


Berdasarkan kategori penilaian semua item hasil uji coba skala besar berkategori baik. Hasil penilaian karakter pada uji coba skala besar terhadap pengembangan model permainan

Tabel 6. Hasil Uji Coba Karakter Skala Besar

\begin{tabular}{cccc}
\hline Penilaian & TM & M & SM \\
\hline Guru Partisipan & 0 & 74 & 136 \\
\hline
\end{tabular}

Hasil penilaian karakter pada ahli materi dan guru penjas pada uji coba skala besar terhadap pengembangan model permainan tradisional mendapat total nilai TM: 0, M: 74, SM: 136 poin dengan presentase TM: $0 \%, \mathrm{M}: 35,2 \%$, dan SM: $64,8 \%$. Jadi dapat di simpul-kan bahwa model permainan tradisional dapat membangun karakter (kerja sama, kejujuran, percayadiri, dan peduli sesama) dengan hasil sebagian besar sangat baik/memenuhi kriteria yang diinginkan. Uji Efektifitas Selanjutnya model permainan tradisional yang diujicobakan pada skala besar ditindaklanjuti dengan melakukan uji efektifitas. Uji efektifitas dilaksanakan di SDN Bendan Ngisor dengan jumlah siswa 32 dengan 6 kali perlakuan. Pelaksanaan uji efektifitas dilakukan dengan menguji dua kategori yaitu karakter dan psikomotor yang terdapat pada KD kurikulum SD. Adapun hasilnya pada Tabel 7.

Tabel 7. Hasil Uji Efektivitas Produk

\begin{tabular}{ccccc}
\hline No. & Uji Efektifitas & Penilaian & $\begin{array}{c}\text { Hasil } \\
\text { Pretest }\end{array}$ & $\begin{array}{c}\text { Hasil } \\
\text { Postest }\end{array}$ \\
\hline 1. & Karakter & Siswa & 602 & 712 \\
& & Guru & 202 & 245 \\
2. & Psikomotorik & Siswa & 209,5 & 250 \\
\hline
\end{tabular}

Dengan melihat hasil perhitungan dengan melihat tabel Indek gain maka dapat disimpulkan bahwa hasil uji efektifitas pengembangan nilai karakter pada pengembangan model permainan tradisional mendapatkan nilai 0,302 terletak pada interval 0,30 $\leq$ 0,70 dengan klasifikasi sedang, dengan kata lain uji efektivitas dikatakan efektif. Berdasarkan uji validitas dan reliabilitas menggunakan bantuan Microsoft Excell 2007, diperoleh hasil sebagai berikut; (a) uji validitas dan reliabilitas instrumen karakter dapat diketahui bahwa seluruh item memiliki nilai korelasi $r$ lebih besar dari $r$ tabel $(0,514)$. Dengan demiikian dapat disimpulkan bahwa item 1 sampai dengan 10 dapat dikatakan valid. Dan dapat diketahui bahwa nilai Cronbach's Alpha diperoleh sebesar 0,914. Nilai tersebut $>0,6$. Dengan demiikian dapat disimpulkan bahwa item 1 sampai dengan 10 dapat dikatakan reliabel, (b) uji validitas dan reliabilitas instrumen guru, dapat diketahui bahwa seluruh item memiliki nilai korelasi $r$ lebih besar dari $r$ tabel $(0,878)$. Dengan 
demiikian dapat disimpulkan bahwa item 1 sampai dengan 22 dapat dikatakan valid, dan dapat diketahui bahwa nilai Cronbach's Alpha diperoleh sebesar 1,00. Nilai tersebut $>0,6$. Dengan demiikian dapat disimpulkan bahwa item 1 sampai dengan 22 dapat dikatakan reliabel, dan (c) uji validitas dan reliabilitas instrumen siswa, dapat diketahui bahwa seluruh item memiliki nilai korelasi $r$ lebih besar dari $r$ tabel $(0,173)$. Dengan demiikian dapat disimpulkan bahwa item 1 sampai dengan 16 dapat dikatakan valid, dan dapat diketahui bahwa nilai Cronbach's Alpha diperoleh sebesar 0,614. Nilai tersebut $>0,6$. Dengan demiikian dapat disimpulkan bahwa item 1 sampai dengan 16 dapat dikatakan reliabel.

\section{Simpulan}

Produk akhir penelitian ini menghasilkan buku pedoman peraturan dan DVD pembelajaran model permainan tradisional untuk membangun karakter demokratis pada siswa SD kelas atas. Hasil semua penelitian berdasarkan perhitungan normatif berkategori baik, berkategori baik artinya model yang dikembangkan dapat mengembangkan karakter siswa, dan model yang dikembangkan sesuai dengan karakteristik dan pembelajaran penjas. Model yang digunakan juga mudah digunakan guru dalam pembelajaran penjas. Uji Efektifitas dengan melihat tabel gain semua penilaian berkatagori sedang, data dalam uji efektifitas berdistribusi normal dan uji t pretest dan postest mengalami perubahan yang signifikan.

\section{Daftar Pustaka}

Departemen Pendidikan Nasional, 2003. Undang-Undang Nomor 20 Tahun 2003, Tentang Sistem Pendidikan Nasional. Jakarta: Depdiknas.

Fudyartanta Ki. 2010. Membangun Kepribadian Dan Watak Bangsa Indonesia Yang Harmonis Dan Integral. Yogyakarta : Pustaka Pelajar.

Kuneifi, Amin Elfachmi. 2016. Pengantar Pendidikan. Jakarta: Penerbit Erlangga.

Noor, Rohinah M. 2012. Mengembangkan Karakter Anak secara Efektif di Sekolah dan di Rumah. Yogyakarta: PT Pustaka Insan Madani.

Rosdiani, Dini. 2013. Perencanaan Pembelajaran dalam Pendidikan Jasmani dan Kesehatan. Bandung: Alfabeta.

Mahbubi M. 2012. Pendidikan Karakter Implementasi Aswaja sebagai Nilai Pendidikan Karakter

Kementrian Pendidikan Nasional Badan Penelitian dan Pengembangan Pusat Kurikulum. 2010. Pengembangan Pendidikan Budaya dan Karakter Bangsa Pedoman Sekolah. Jakarta: Kementrian Pendidikan Nasional. 